\title{
Chapter 17 \\ Recruitment of Skilled Employees and Workforce Development in Germany: Practices, Challenges and Strategies for the Future
}

\author{
Thomas Deissinger and Kathrin Breuing
}

\begin{abstract}
This chapter focuses on workforce development in the German context. Two issues are relevant: the first one deals with the links between the standard form of initial VET, that is, the dual apprenticeship system, and formalised further training, which in its various facets has a major function in the German context when it comes to career building, but also to establishing a craft business. Second, companies in Germany, as in other countries, use internal schemes of personnel development and further training to maintain their workforces both in quantitative and qualitative terms. A crucial challenge currently seems to be demographic change, and the way companies try to cope with his challenge has led to new forms of incompany personnel development that were unknown in the past. Both aspects are discussed in this chapter.
\end{abstract}

\section{Introduction}

Workforce development in Germany is partly associated with formal initial and continuing training, but also depends on what companies consider functional with respect to their employees. Besides these formal pathways companies have developed individualised patterns of workforce development, partly as 'branch' typical further training, partly as job-specific ways of competence adaptation in the workplace. Therefore, personnel development, in which training activities play a major role, has no real 'system character' as it is rather heterogeneous building on organisational and economic patterns - quite in contrast to the pedagogical dimension which is a core element of most formal training. Hereby, the so-called dual system has the function of imparting skills for occupations in relevant technical

T. Deissinger $(\bowtie) \bullet K$. Breuing

Department of Business and Economics Education, The University of Konstanz,

Konstanz, Germany

e-mail: thomas.deissinger@uni-konstanz.de 
and commercial sectors of the economy. Against the background of a 'mental pattern' according to which companies and public stakeholders in common feel responsible for the training and recruitment of skilled workers and commercial experts with qualifications below degree level, the system also offers opportunities for the workforce to use their qualifications for further training, be it formal or informal. One of the typical examples for this is the "master worker/craftsman qualification'. Although workforce development within companies appears to be a rather heterogeneous concept, the German frame of mind holds that an initial vocational qualification normally should be a prerequisite for a career in a company. In recent years, besides the 'non-academic' apprenticeship track, higher education degrees have grown in importance in the German context. This means that new patterns of 'tertiarisation' of VET begin to change the architecture of the German education system. With it, the social composition of the workforce in companies, especially in industrial enterprises, is changing, although this cannot be said of the craft sector which still recruits its workforce in a more or less traditional way.

The following sections focus on two aspects we consider to be relevant for this discussion on workforce development, that is, the links of continuing training and personnel development in and for company workplaces with initial training, especially the apprenticeship system, and the issue of how companies try to cope with changes in their environment - with demographic change at the forefront - to maintain the quality of their workforce in the future.

\section{The Standard Pathway for Skilled Workers: The Dual System of Apprenticeship Training}

Germany may be characterised as a country with a 'mass apprenticeship system' based on a strong occupational identity of those holding the corresponding qualifications (Ryan 2003, p. 150). Also in quantitative terms, apprenticeships represent the dominant pattern of initial skill formation below degree level as well as of socio-economic integration into the labour market (Steedman 2010; Deissinger 2010, Deissinger et al. 2012). Since companies normally recruit their apprentices from the lower stratum of the education system, the links between school education and VET are comparatively strong. Although some $15 \%$ of apprentices hold some kind of higher education entrance qualification (Abitur or Fachhochschulreife), the majority of school leavers are students who have either no aspiration or the possibility to take up studies at a university or other higher education institutions. The specific 'apprenticeship culture' typical for non-academic initial vocational training in Germany has a long-standing cultural dimension (Deissinger 1994), and, despite its medieval origins and 'old-fashioned' terminology, still is one of the pivotal topics of national VET policy. The general significance given to apprenticeship as an institutional solution for the problem of skill formation normally depends on the political focus and the economic relevance of the interaction or 
interdependence between VET on the one hand and general and higher education on the other. Besides the apprenticeship system, school-based forms of vocational learning, such as 'vocational colleges', also represent more or less traditional courses and qualifications, which are normally institution-based, shaped by state influence and more or less clearly didactically-steered, pedagogical arrangements. There are, however, differences when it comes to formally linking up these traditional structures with other forms of vocational learning. The reason for this is the overall importance which companies dedicate to the dual system when it comes to recruiting skilled workers, artisans or commercial experts below the academic (Master or Diploma) level.

The cultural imprints for this kind of initial vocational training as the first cornerstone of workforce development become obvious once one compares the 'Germanic' model (also strong in Austria and the German-speaking cantons of Switzerland) with 'Anglo-Saxon' solutions for the problem of skill formation. Here, beyond the institutional peculiarity of both general and technical education in a vocational school besides learning in the workplace, the understanding of vocational pathways (Harris and Deissinger 2003) and the value given to VET in general appear to be unique in the international context. These traits of German VET become manifest when we look at the challenges imposed by the European Union with its Lifelong Learning policy and one of its derivates, the European Qualifications Framework. It seems that countries that differ in terms of their VET systems and traditions, especially with respect to the relationship between fulltime VET and company-based training, such as apprenticeships, also differ in terms of their adaptability to the overarching European VET policy ideas. One of these ideas is the conceptualisation of National Qualifications Frameworks (NQF) (Young 2003). Work on Germany's NQF had to pick up the issues of re-defining borders, pathways, levels and transition options between VET and other educational sub-systems, and the same for sub-systems within the VET system such as full-time VET, vocational preparation, vocational introductory courses and further training. The result, being rather an incomplete answer to Europeanisation, has been a re-confirmation of the overall significance of apprenticeships and also of continuing training in its wake (master craftsmen, technicians etc.) to which the NQF pays special tribute by, for example, placing the master craftsman qualification (Meister) on the same level as a bachelor degree. This positioning once again underlines the social and economic importance of the apprenticeship system. In a recent press release, the president of the German Chamber Association (DIHK) 'warns' that 'uncontrolled academisation' could be a wrong way for Germany to solve its qualification and recruitment problems in the future (Schweitzer 2014, n.pag.). The background of this warning is the unquestioned outlook that the German economy will run into serious skill shortages in the future due to a demographic curve that is sliding.

Both institutionalisation and didactical standardisation form the basis of the kind of training typical for the German 'learning culture' in the apprenticeship system (Harris and Deissinger 2003). In this system, with its 350 recognised training occupations, the commitment and interest of chambers, trade unions and companies are 
crucial and therefore the needs of companies and workplace developments as well as organisational or technological changes normally stand at the beginning of establishing or modernising a training scheme. Training schemes, quite in contrast with England or Australia, are comprehensively regulated patterns of vocational qualifications that require a fixed training time, curricular regulation on the side of the vocational school, compulsory general and technical education in school as well as a final examination before the chamber. A specific pedagogical component comes in with the compulsory subjects provided through school attendance in the part-time vocational school, which stands both for theoretical vocational learning as well as general education during the apprenticeship. Ryan puts this in contrast with the British approach to VET: 'A striking difference from Germany is the absence of minimum training periods, such as a 3-year program for bakers. Similarly, apprentices need not take part-time technical education' (Ryan 2001, p. 136). The Vocational Training Act provides for all these regulatory aspects with respect to company-based training (Deissinger 1996). It places vocational training in the hands of firms and chambers and thus emphasises the principle of self-government (Zabeck 1975). At the same time, the Act takes account of traditional features of guild apprenticeships while simultaneously submitting in-company training to homogeneous, supervisable and examinable standards. The 'competent authorities' function not just as examining bodies but also as monitoring agencies for incompany training.

Modernisation within the dual system currently seems to happen mainly on the curricular level. It has materialised in the creation or revision of training schemes within the system of 'skilled training occupations' which now even allow for modest features of modularisation. Implanting modules within training schemes as didactical units with a mandatory but optional character (like in the IT occupations created in 1997) no longer seems to be incompatible with a holistic notion of competence (Euler 1998, p. 96ff.). At the same time, curricular provisions which take account of new technological developments and/or needs of companies to react quickly to these changes, including more flexibility for training, are now much more relevant than some 20 or 30 years ago, when major modernisation activities began to 'cleanse' the existing system of training occupations. Today, using modules in a more open manner means that companies can adapt their workforce development at the state of initial training to their specific organisation and technologies, although there is a general conviction in the research community that the system has to become even more flexible (Euler and Severing 2006; Baethge et al. 2007). On the other hand, interest groups, such as trade unions and chambers, are eager to underline their belief in the efficiency of the dual system as the 'royal road' into skilled employment.

Table 17.1 shows the relevance of apprenticeship training for the two major sectors of the German economy, namely, industry and trade (including commercial occupations) and the craft sector. It also illustrates the fact that the dual system is basically a pathway outside higher education for graduates from lower and intermediate secondary schools (Haupt- und Realschulen), but also that branches differ when it comes to predominantly recruiting school leavers from these secondary schools. 
Table 17.1 Training sectors in the German economy and dominant qualifications of apprentices

\begin{tabular}{lcl}
\hline & $\begin{array}{l}\text { Number of entrants into an } \\
\text { apprenticeship (2012) }\end{array}$ & $\begin{array}{l}\text { Most prominent school qualification } \\
\text { of apprentices (2011) }\end{array}$ \\
\hline Industry and trade & 332,622 & Intermediate secondary $=43.6 \%$ \\
Crafts & 147,327 & Lower secondary $=52.0 \%$ \\
Public service & 12,102 & Intermediate secondary $=49.0 \%$ \\
Agriculture & 13,260 & Lower secondary $=45.7 \%$ \\
Professions & 43,014 & Intermediate secondary $=56.4 \%$ \\
Home economics & 2,763 & Lower secondary $=58.3 \%$ \\
Maritime & 183 & No information available \\
Total no. of entrants & $\mathbf{5 5 1 , 2 7 1}$ & \\
\hline
\end{tabular}

Source: Bundesinstitut für Berufsbildung (2013, p. 170)

This also means that continuing training and personnel development of the German workforce are closely intertwined with the school system.

\section{The Architecture of Formalised Continuing Training Against the Background of the German Apprenticeship System}

There are five major types of further training qualifications at sub-degree level which, in the German context, are relevant for either self-employment or for incompany careers. All these qualifications require completion of an apprenticeship or an equivalent skills level, and they lead individuals to a qualification level which is located above the level of a normal apprenticeship qualification:

- Master craftsmen or master workers (Meister)

- Industrial or commercial specialists (Fachwirte)

- Technicians (Techniker)

- Business specialists (Betriebswirte)

- In-company trainers (Ausbilder)

Whereas the qualifications of master craftsmen, industrial specialists and trainers (engaged in training apprentices in the dual system) require a chamber examination, technicians and business specialists receive their further training in a vocational school and have to take examinations which are defined and held by the respective federal state's school administration. Vocational schools in Germany are complex institutional entities (Deissinger et al. 2006), with the part-time vocational school normally being the largest segment, but they also comprise, besides the various fulltime vocational courses, further training classes with technical or commercial specialisation, among which those for technicians belong to the most relevant ones. These classes, called Fachschulen, can only be attended after having completed an apprenticeship, and can also be combined with a Fachhochschulreife (entrance qualification for universities of applied sciences). A crucial prerequisite, however, is 
Table 17.2 Formal further training qualifications in Germany

\begin{tabular}{lllll}
\hline Number of passed examinations & 2002 & 2010 & 2011 & 2012 \\
\hline $\begin{array}{l}\text { Master workers (Industriemeister), industry } \\
\quad \text { or commerce }\end{array}$ & 9,368 & 9,678 & 11,325 & 9,966 \\
$\begin{array}{l}\text { Master craftsmen (Handwerksmeister), crafts } \\
\text { Industrial or commercial specialists (Fachwirte) }\end{array}$ & $-26,674$ & 19,659 & 22,236 & 22,674 \\
Technicians (Techniker) & - & 15,084 & 16,887 & 17,298 \\
Business specialists (Betriebswirte) & - & 15,978 & 18,897 & - \\
In-company trainers (Ausbilder) & 59,913 & 6,105 & 3,552 & 3,624 \\
\hline
\end{tabular}

Sources: Bundesinstitut für Berufsbildung (2013, pp. 226f., 373, 380), id. (2012, p. 310), id. (2009, p. 283f.), Statistisches Bundesamt (2013, pp. 115, 375ff.)

occupational practice after the initial training in the apprenticeship system (normally 3-5 years). Therefore, an industrial technical worker (e.g. Industriemechaniker) would be able to climb up the qualification ladder either by attending a Fachschule (technician) or a master worker course in a vocational school, a chamber or with a private training provider.

Most formal continuing training qualifications (Bundesinstitut für Berufsbildung 2013, p. 368ff.) are based on the Vocational Training Act (VTA) or the Craft Regulation Act (CRA). The VTA characterises formal further training, besides re-training and initial training, as an instrument to enable individuals to maintain and extend their vocational competences, to gear them to technical change or to climb up the vocational ladder (Aufstiegsfortbildung). In institutional terms, this kind of formal further training is laid down in further training regulations, which have to incorporate, besides examination standards, a clear denomination of the further training occupation, the objectives pursued by the training measure and admission prerequisites for entering the course (sections 53 VTA/42 CRA). Altogether, on the federal level, there are 223 further training regulations. Besides, the chambers also can define legal provisions for the regulation of courses: all in all, these institutions have implemented a total of some 2,500 covering some 750 further training occupations.

Table 17.2 provides statistical information on the various types of institutionalised further training in Germany.

Among these qualifications and underlying VET courses, the Meister is a qualification which has its roots in the craft sector, but now also exists in the industrial sector (Industriemeister). It is interesting that, from a language point of view, the denomination 'Meister' has a number of different meanings (e.g. also indicating the status of conductor or composer in a cultural meaning of this term), but when it comes to vocational training it is a 'protected' term: the occupational status is strictly associated with the respective chamber examination (Meisterprüfung). The same applies to the 'Industrial Meister' (Industriemeister), but not to people who possess a special organisational status in a company and are normally called Werkmeister - which does not require a special continuing training qualification at all but can be achieved via the organisational ladder in a company. This, however, also implies that Werkmeister can be relevant people when it comes to training 
apprentices since they have a lot of professional experience. In the German context, we also find expressions using the word Meister with respect to a special area of competence where people work, such as Baumeister (a person designing churches) or Bademeister (a person working in a public swimming pool as a supervisor). These denominations, however, are not the result of formal continuing training, but are mostly based on normal training qualifications or simply depict occupational responsibilities in a special area of employment. Even in the public sector we find the term Meister - for example, a mayor is called Bürgermeister. Last but not least, Goethe's novel Wilhelm Meister puts emphasis on a young man's personal and occupational development by emphasising the status of the Meister beyond the qualification dimension of this term. Here it becomes clear that the human being is directed to 'walk' on a vocational pathway which is deeply educational, since it focuses on the notion of 'craft' which stands for the human existence maturing through experience and practical work (Zabeck 2013, pp. 235ff.; Wilhelm 1957, p. 48).

Both in the present and in a historical reflection, the most interesting qualification in the context of further training in Germany certainly is the master craftsman qualification, which has a history reaching back to the rise of the guilds in the Middle Ages (Zabeck 2013, pp. 46ff.). The importance of this type of occupational status is the fact that the craft sector is a strong supplier of training places in the apprenticeship system which is due to the interesting legal regulation that a master qualification (both in industry and in the craft sector) includes the trainer qualification according to the Vocational Training Act (Bundesministerium für Bildung und Forschung 2005).

This Act not only stipulates the rights and duties of trainees and training companies but also prescribes the personal and technical skills of training personnel, which may be characterised as a special group of employees who have undergone formal continuing training as part of workforce development. Hereby, the Act distinguishes between the trainer and the person or firm taking on apprentices (sections $27 \mathrm{ff}$.). The 'personal aptitude' (persönliche Eignung) means that a person must not have disobeyed the Vocational Training Act and has to be eligible to employ young people. These preconditions are sufficient for hiring an apprentice. However, a person engaging in apprenticeships also has to prove the competence for instructing the apprentice at the training site, called the 'technical aptitude' (fachliche Eignung) unless there is a training officer having the necessary personal and technical qualifications to provide the training (sections 28ff.). Therefore the trainers themselves, besides their 'personal aptitude', must avail of technical (i.e. occupational) and pedagogical abilities and knowledge, which means that they not only have to be expert in their occupation but also have educational and psychological skills, including the application of appropriate teaching and instruction methods. In 1972, the trainer qualification became formalised and was decreed as the Ausbildereignungsverordnung (AEVO), which outlines the curriculum for trainer courses normally offered by the 'competent authorities', mostly the chambers (Weber 1985, pp. 60-64).

By stressing the trainer qualification as one of the most important formal, continuing qualifications in the German VET system, the Vocational Training Act has 
paid tribute to the different historical developments in the craft sector and the branches of industry and commerce. Its stipulations have led to an adaptation and revision of already existing regulations such as the master qualification. In 1972, the Allgemeine Meisterprüfungs-Verordnung (General Ordinance for the Master Examination) adopted the AEVO as Part IV of the syllabus governing master training courses (Schwichtenberg 1991, p. 27). The master undoubtedly still represents the major career aspiration of craftsmen and industrial workers, but training as an organisational and educational function has now been opened to a broader range of qualified people including university graduates and, above all, skilled workers, clerks or journeymen. As an innovative measure, the implementation of the 'technical aptitude' in its more extensive meaning including the occupational and the pedagogical aspect has certainly contributed to the 'upgrading' of training as an educational activity and not merely as a part of a company's personnel management (Arnold and Hülshoff 1981).

Against this background, the Vocational Training Act represents the first comprehensive set of legal regulations for in-company initial training as well as continuing training and retraining (section 1) - which may be seen as a continuum of skills formation under the common auspices of companies and the state:

(1) For the purposes of this Act the expression 'vocational training' means initial training, further training and retraining. (2) The object of initial training shall be to provide, through a systematic training programme, a broadly conceived basic preparation for an occupation and the necessary technical abilities and knowledge to engage in a skilled form of occupational activity. Initial training shall also enable a trainee to acquire the necessary occupational experience. (3) Further training shall be designed to enable a trainee to maintain or extend his vocational knowledge and abilities, adapt himself to technical developments or obtain promotion in his chosen occupation. (4) Retraining shall be designed to qualify a trainee for another form of occupational activity.

The history of vocational training legislation reflects the fact that, both in theory and in practice, the notion of the workshop and the idea that an apprentice should learn his trade under an experienced master worker form the roots of German 'training culture'. The historical differentiation of Meister, Geselle (journeyman) and Lehrling (apprentice) or Auszubildender (trainee) is still prominent in the craft sector, which represents some 100 training occupations in the dual system, and is based on special regulations laid down in the Handwerksordnung (Craft Regulation Act). Up to the present day, apprenticeships in Germany are based on two legal foundations, namely the above-mentioned Craft Regulation Act (1953) and the Vocational Training Act (1969/2005). Both stand for the vocational/occupational orientation of training within a reliable legal and institutional framework (Deissinger 2009). The notion of training quality standards within each trade, in fact reaching back to the medieval guilds, was re-strengthened in the nineteenth century when industrialisation had begun to change the modes of production and technologies in a number of sectors of the economy. Hence the craft tradition never disappeared completely, since it became the focus of government economic and social policy - and with it the master craftsman qualification that became a crucial part of this 'renaissance': 
- In 1845, a Prussian Trade Act (Stratmann and Schlüter 1982, pp. 122ff.), though not repealing freedom of work as a whole, re-imposed restrictions on free craftsmanship by confining the privilege to take apprentices to masters who belonged to a guild in as many as 43 trades. The Act made a precise distinction between small workshops and industrial premises by linking the right to take and train apprentices in handicraft occupations to examined journeymen (Stratmann and Pätzold 1984, pp. 117-119).

- In 1897 a trade act (Handwerkerschutzgesetz) re-introduced the requirement of formal vocational skills to train apprentices in the craft sector. Although it did not yet set up the master certificate as a training prerequisite (Knörr 1996, pp. 142ff.), it revived some important stipulations included in the ancient apprenticeship mode. Thus chambers and guilds were assigned to organise examinations for journeymen or masters. Also, indentures as well as a 3-year training period at the end of which the apprentice took his examination (Stratmann and Pätzold 1984, pp. 123f.) became a general and virtually mandatory practice in the craft sector.

- In 1908, the right to train apprentices was confined by law to examined handicraft masters (Winkler 1976, p. 2), and finally, in 1935, the trade law was changed again in favour of the old-established occupations, with the re-introduction of the master qualification as a prerequisite to establish a craft business, still prescribed in current German trade law (Knörr 1996, pp. 169ff.).

Against this historical background, the German model of workforce recruitment and workforce development is, at least partly, a highly formalised one. The reason for this is that the traditional features of vocational orientation and self-government are not only rooted in the medieval notion of occupation-specific craftsmanship. The social, technical and economic relevance of the master craftsman qualification, as it is seen today, is underlined by the fact that this type of a higher vocational certificate is represented in the German Qualifications Framework (DQR) on level 6, which is based on a decision taken in February 2012 by the federal government, the federal states and the social partners. This allocation of a non-academic qualification - the same applies to the above-mentioned 'technician' - on the same level as a bachelor degree clearly mirrors the crucial political attention which VET in Germany is being given even in times of a creeping 'tertiarisation' of its vocational and educational pathways. Hereby, 'equivalence', not 'uniformity' is seen as a justification for this positioning of continuing VET (Bundesministerium für Bildung und Forschung 2011).

The formal dimension of the German Qualifications Framework, however, collides with a consistent policy of 'opening up barriers' in order to enable individuals to proceed from one sector of the education system to another. The fact that master craftsmen now can apply for permission to university studies stands for a stronger political focus on 'parity of esteem' in the wake of the EU's Lisbon-Bologna strategy, incorporating the notion of lifelong learning as a crucial overarching topic (Hake 1999). There is still awareness, though, that vocational qualifications have another function than academic ones. Positively speaking, this means that VET is 
still predominantly seen as a specific sub-system with its own 'self-reference' (Luhmann 1984) and functionality, especially once one sees the master craftsman qualification as a logical upgrading of an apprenticeship.

Research shows that, in Germany, at least for the time being, vocational qualifications have not yet entered serious competition with academic ones (Hippach-Schneider and Weigel 2012). Companies demand different levels of qualifications, depending on the various functions in the organisation. However, it may be claimed that access to university or other higher education institutions is now more articulated as a social aspiration by many young people. In some way, the so-called 'vocational academies' have satisfied these aspirations. Starting in the 1980s, in the federal state of Baden-Württemberg (Deissinger 2000), the 'dual universities', as they are called today, are a kind of 'academic dual system', and stand for one type of 'tertiarisation' of VET, which is likely to have long-term implications for the apprenticeship system, but also for in-company workforce development. It is likely that, in Germany, pathways that resemble the dual system will remain attractive to employers. In contrast, from a European comparative perspective, it may also be stated that in Germany 'hybrid qualifications', combining vocational with academic entitlements (e.g. the university entrance qualification), are less interesting and relevant in the VET policy context (Deissinger et al. 2013). This once again underlines the importance of certificates that are portable in the labour market and therefore meet the demand of industry in the first place. It has been outlined in this part of the paper that the respect for VET in general and the strong focus on apprenticeship qualifications (Harris and Deissinger 2003; Deissinger 2010) have a number of major implications not only for continuing training but also for in-company workforce development practices.

\section{Workforce Development in the Face of Demographic Change - Knowledge Transfer Strategies of German Companies}

In the following, our focus shifts to the organisational level, that is, the corporate level. The notion of workforce development is discussed in the context of demographic change and the corresponding ageing and shrinking of the German working population. What measures and strategies do German firms adopt in order to tackle the demographic development on the labour market? While addressing this question, special attention is given to the aspect of intergenerational transfer of knowledge.

Demographic change has already been a prominent issue in German society, politics and economy for years. The prospect of an increasingly ageing workforce accompanied by a shortage of skilled workers not only alarms employers but also the federal government and the federal states, social security institutions, industry associations and trade unions (Eck and Bossmann 2013, pp. 15f.). Before focusing on the corporate level and the measures taken there to cope with demographic 
challenges, the phenomenon of demographic change shall be depicted with respect to the German population and its impact on the German job market.

\section{Demographic Change and Its Impact on the German Labour Market}

Demographic change is mainly influenced by two factors: population decline and the changing age structure of the population (Statistisches Bundesamt 2009, pp. 5, 12ff.; Statistische Ämter des Bundes und der Länder 2011: n.pag.). Given the continuation of the current demographic development, the Federal Statistical Office predicts a decline of the German population from about 81 million people in 2013 to 65-70 million in 2060 (Statistisches Bundesamt 2009, pp. 5, 46). At the same time, a serious shift of the age structure can be expected. Significant changes will already take place over the next few years, particularly the age groups of 50-65 years $(+24 \%)$ and $80+$ years $(+48 \%)$ will grow until 2020. The number of people under the age of 50, however, will decline $(-16 \%)$. By 2060, every third person $-34 \%$ of the whole population - will be 65 years and older and the number of 70 -year-olds will be twice the number of new-born children (ibid., pp. 5, 16).

Demographic change is reflected most significantly in the working population: it is this population (age range from 20 to 65 years) that is particularly affected from shrinking and ageing (ibid.: 17). According to the prognosis of the Federal Statistical Office, the German economy will already have to deal with a radical change of its age structure from the year 2017 to 2024 . In between, $40 \%$ of the potential workingage population will be 50-65 years old (ibid., pp. 6, 18). Until 2060, the potential working-age population will decrease by $27-34 \%$ (depending on immigration) compared with the 2008 baseline (ibid., p. 17).

Ten years ago, the human resource policy of many German companies was based on the so-called 'deficit model' of ageing - assuming a negative relation of age and achievement - and was characterised by early retirement and youth-oriented recruitment strategies. Today, shortage of labour supply has become reality for many industries and has fostered a change in mentality away from the deficit model towards a potential-oriented perspective on age. Older employees are increasingly valued as an indispensable resource (Bundesinstitut für Berufsbildung 2005, p. 2; Bossmann et al. 2013, pp. 47f.; Cihlar et al. 2014, p. 13; Eck and Bossmann 2013, p. 22; Lesser et al. 2005, p. 3; Seitz and Wagner 2009, p. 170; Wegge et al. 2011, p. 433). The impending shortage of skilled workers arising from demographic change has also forced politicians to react. On the one hand, in order to prolong working life, the early retirement policy of recent years was cut back and the legal age of retirement was raised to 67 years. On the other hand, periods of schooling and training were shortened, aiming at an earlier entry into the labour market for young people (Wegge et al. 2011, p. 434; Eck and Bossmann 2013, p. 22). 
As a result of these developments and measures, companies are now facing a fundamental change in the age structure of their workforce - namely, an extension of the age range (Walter et al. 2013, p. 64; Wegge et al. 2011, pp. 434, 441). Different age groups with different strengths and weaknesses meet in the workplace (Bossmann et al. 2013, pp. 45ff.; Cihlar et al. 2014, pp. 14f.; Walter et al. 2013, p. 58; Wegge et al. 2011, pp. 433, 439; Zimmermann 2005, pp. 26f.; Zwack and Schweitzer 2013, pp. 105ff.). Even more importantly, different generations with different values, needs and ways of thinking and working are having to get along with each other (Klaffke and Schwarzenbart 2013, pp. 45f.; Meyers 2009, pp. 202ff.; Schenck 2013, p. 130; Walter et al. 2013, pp. 61f., 64; Wegge et al. 2011, p. 434). The main challenge for companies is to embrace this diversity and to convert the tensions between generations into innovative and creative forces (Seitz and Wagner 2009, p. 159; Klaffke and Schwarzenbart 2013, p. 45). However, cooperation of employees of different age groups and generations, as it has increasingly become indispensable for companies in order to remain competitive, can only work if:

- the post-war generation (1946-1955),

- Baby Boomers (1956-1965),

- Generation X (1966-1980),

- Generation Y (1981-1995) - also known as Millennials - as well as

- Generation Internet (1996-today)

become involved with each other and adopt mutual tolerance, respect and understanding (Klaffke and Schwarzenbart 2013, p. 45; Meyers 2009, pp. 210ff.; Oertel 2007, pp. 289ff.; Schenck 2013, p. 130; Walter et al. 2013, pp. 61f., 64; Wegge et al. 2011, p. 434).

\section{Intergenerational Transfer of Knowledge as a Key Factor for Corporate Success}

Besides demographic change, companies have to cope with other megatrends such as intensified competition due to globalisation, shorter reaction times, rapid technical progress as well as the transition towards a knowledge and innovation society (Eck et al. 2013, pp. 36, 41f.; Piorr et al. 2006, p. 83; Schenck 2013, p. 125; Seitz and Wagner 2009, pp. 157, 170; Walter et al. 2013, pp. 25f.). As demographic change has coincided with the emergence of knowledge as a key resource, cooperation of young and old employees becomes increasingly important with regard to in-company transfer of (experience-based) knowledge. Thus, the uncoordinated loss of know-how due to age-related retirements of experts can cause massive problems for companies under current market conditions (Piorr et al. 2006, p. 83; Seitz and Wagener 2009, p. 157). Therefore, enterprises should implement an age-based 
personnel policy combined with a demography-robust management of knowledge to counter the loss of valuable know-how at an early stage and to keep the innovation potential of an ageing workforce alive at the same time (Schenk 2013, pp. 125f.; Walter et al. 2013, p. 48; Wegge et al. 2011, p. 435).

A survey of human resource managers in the chemical industry in 2006 showed that many companies are aware of the consequences of the demographic trend and respond to these challenges by fostering a preventative conservation of internal knowledge. However, there is still a considerable share of firms that do not take any measures at all in order to avoid the loss of know-how (Bader et al. 2009, p. 38). Overall, $52.3 \%$ of the 198 human resources managers surveyed (gross sample size: 1,311) think that the demographic development will have negative impact on their companies (90.9\% of which are big companies) in the nearer future. Some of the companies have already implemented concrete measures to promote knowledge transfer: $75.4 \%$ work with mixed-age teams and $31.8 \%$ have introduced tandem models. However, $10.8 \%$ of the companies state that they do not foster the exchange of experience and knowledge at all (ibid., p. 38).

Similar data result from a nationwide survey of 537 firms (gross sample size: 1,582) conducted by the Federal Institute for Vocational Education and Training in 2004. Although merely one third (31.3\%) of the respondents felt affected (by the time of the interview) by demographic change (Bundesinstitut für Berufsbildung 2005 , p. 1), $81.1 \%$ of the companies said that they promoted knowledge transfer between the older and the younger employees. The most frequently mentioned model is mixed-age teams $(72.2 \%)$, followed by support of newcomers by older employees (mentoring, sponsorship, coaching or tandem programs) with $59 \%$. A large proportion of companies also offer further training on this subject (42\%). Additionally, meetings and workshops, internal seminars, knowledge databases as well as in-company training were mentioned. Considering the firm size, it is the larger companies in particular that actively boost the exchange of knowledge and know-how (ibid., p. 4; Zimmermann 2005, p. 27).

While knowledge transfer was originally regarded and applied as transmission of (specific) experience-based knowledge from older employees to younger colleagues, the idea of mutual learning, with both old and young colleagues acting as knowledge-providers and -recipients, has become increasingly popular. Approaches that are specifically directed to the needs of older employees bear the risk of focusing too strongly on this age group and excluding the younger colleagues. Therefore, human resource development strategies should be enhanced by the aspect of intergenerationality - which means that motivation and working ability of all age groups have to be strengthened. 'The new' should get its chance and 'the old' its recognition (Seitz and Wagner 2009, pp. 159f.). By working together cooperatively, both sides learn from each other - the combination of the up-to-date knowledge of young recruits and the expertise of older colleagues generates added value for companies (ibid., pp. 157, 170; Klaffke and Schwarzenbart 2013, p. 45; Zimmermann 2005, p. 27). 


\section{Mixed-Age Teams and Mentoring Programs - Examples from the German Economy}

In this part of the chapter, two forms of knowledge transfer are highlighted that play a crucial role not only in literature but also in practice (as the data above show): mixed-age teams - providing for a balanced mix of employees in different phases of working life - and mentoring or tandem programs, allowing older employees to look after their younger colleagues or share a common project with them. First, selected examples from the German economy are presented. Then, possible problems connected with the implementation of the two approaches are described.

The implementation of mixed-age teams is an essential step in boosting knowledge transfer at AUDI AG, one of the biggest German car manufacturers. The following quotations show that the company has developed an intergenerational, that is mutual, understanding of knowledge transfer and learning:

Our employees work in a dynamic environment shaped by constant change and innovation. Therefore we embrace the concept of 'lifelong learning' - for example, by setting up mixed-age teams, in which all the members learn from each other and pass on their knowhow, both to young talents and to experienced colleagues. For us, experience is not a matter of age but of commitment. (AUDI AG 2014, n.pag.)

The advantage of mixed-age teams lies in different characteristics, values, work routines and pieces of experience contributed by different generations. The broader the variation in a team, the more versatile are the solutions offered - and the better is the result in the end. And that is exactly what we need, as cars are very complex products. (Frassek, Project Manager and Demography Expert of AUDI AG, Frassek 2014, n.pag.)

For SICK AG, a German company and world leader in sensor technology for industrial application, the cooperation within mixed-age teams also is a crucial measure in order to cope with demographic change. With the aim 'to link the experience, dedication to quality, process know-how and social integrity of our older employees with the curiosity, up-to-date technical know-how, new methods and often higher speed of the new generation' (Kast, CEO Human Resources of SICK AG, qtd. in SICK AG 2010, p. 2), the company relies on the cooperation of generations and expects the following advantages, among others:

We are offered different perspectives. Thus, the quality of decision and troubleshooting processes improves. New insights and ideas are possible.

The wider span of age in the teams enhances the personal networks. The number of contacts rises, as younger and older colleagues often have different contact persons.

The daily exchange at work facilitates mutual competence enhancement - the members of mixed-age teams train each other. (SICK AG 2010, pp. 8f.)

Knowledge transfer is possible even after senior employees have left the company, as the following two examples show. The German Bosch Group, a leading global supplier of technology and services, uses the experience of so-called 'senior experts'. The Bosch Management Support GmbH (BMS), founded in 1999 with the aim to offer counselling by Bosch-retirees and to keep their specific skills and knowledge in the company, builds the foundation for this endeavour (Robert Bosch 
GmbH 2009, p. 1f.). Senior experts are contacted whenever quick, short-term and professional advice is needed. By supporting their younger colleagues, senior experts create 'an intergenerational exchange in terms of mutual learning. While our junior managers can introduce their senior colleagues to new software for example, BMS-experts are able to fall back on decades of experience in leadership, motivation and technical know-how' (ibid., p. 2).

Daimler AG, one of the biggest car manufacturers in the world, has established generation management as a strategic initiative in their corporate strategy. The company started a program similar to BMS at the Bosch Group: the initiative 'Space Cowboys - Daimler Senior Experts'. With the objective to strengthen knowledge transfer between experience bearers and newcomers in the company, Daimlerretirees temporarily get back to work in their former departments at Daimler (Daimler AG 2013, n.pag.):

\begin{abstract}
For our success both factors are important: innovative capacity and comprehensive experience. By means of our initiative 'Space Cowboys - Daimler Senior Experts' we aim at the cooperation of different generations with their very own, specific qualifications. The multitude of their know-how and perspectives contributes vastly to the realization of our growth strategy. (Porth, Member of the Board of Management of Daimler AG, Human Resources and Director of Labour Relations, qtd. in Daimler AG 2013, n.pag.)
\end{abstract}

A special and innovative approach, awarded by the German Federal Ministry of Education and Research, was developed and implemented at the Mercedes-Benz plant in Bremen (Germany). Here, experienced employees receive training for new occupational profiles alongside young apprentices. The concept is called 'Intergenerational Qualification (IQ)' and aims at generating synergy from the individual qualifications of different age groups (Daimler AG 2014, n.pag.). In the training programs for tool mechanics and cutting machine operators, older employees who were looking for further training have been working side by side with young apprentices since 2011. Two senior employees who take part in this program give an account of the project:

\footnotetext{
We applied for the programme because we wanted to learn something new. To go back to school after more than 20 years might have been the greatest hurdle. We had to learn how to learn again.

The interaction of young and old colleagues is what I like most about the programme. It is a special experience to work with the other apprentices that could have been our own children. They sometimes support us at school, because they are still used to this learning environment. When it comes to mechanical skills, it is just the other way round: the experienced colleagues can help the younger ones. (Daimler AG 2014, n.pag.)
}

The finding that older employees are motivated by the cooperation with junior colleagues is also backed by a recent study published by the ZEW (Centre for European Economic Research). On the basis of data collected from German enterprises, researchers were able to show that mixed-age teams make older employees stay in the company for a longer period of time - contrary to partial retirement programs or further training offers that have less impact or no impact at all (in the case of partial retirement programs) on the duration of employment (Bockmann et al. 2013; Cihlar et al. 2014, p. 15; Walter et al. 2013, p. 60). 


\section{Obstacles and Challenges for Intergenerational Knowledge Transfer}

Empirical studies show that mixed-age teams and mentoring programs may not only have positive effects, but also negative ones - in terms of ineffective cooperation (e.g. Joshi and Roh 2009; Ries et al. 2010; Wegge et al. 2008). Wegge et al. warn about viewing mixed-age teams as the 'cheap solution' to demographic problems in companies. The authors point out that co-working in mixed-age teams needs to be well-prepared and continuously observed and accompanied for intergenerational cooperation to work (Wegge et al. 2011, pp. 434ff.). Based on the findings of the ADIGU-project (Age Heterogeneity of Work Groups as a Determinant of Innovation, Group Performance, and Health), funded by the German Research Foundation (DFG), Wegge et al. derive five recommendations for business practice - mixed-age teams may be (especially) successful if:

1. the perception of age differences is marginal,

2. there is a positive climate in the team, free of age discrimination and prejudice,

3. the appreciation of age differences is high,

4. the group work includes complex tasks, and

5. the corporate and leadership culture in the company accepts and values age, experience and individual potentials of employees (Wegge et al. 2011, pp. 437ff. see also Klaffke and Schwarzenbart 2013, pp. 44, 47; Oertel 2007, pp. 251ff., 282ff.; Seitz and Wagner 2009, pp. 163f.; Tomenendal 2013).

Zimmermann (2005) and Bader et al. (2009) point out that there are a number of preconditions for successful knowledge transfer in mentoring and tandem programs. Zimmermann mentions trust, mutual appreciation and a common aim as promising conditions for knowledge transfer. In terms of a reciprocal learning process both sides have to benefit from their cooperation - knowledge transfer must not be perceived as a one-way street. As knowledge transfer normally includes the transformation of implicit (practical) knowledge into explicit (verbalised) knowledge, mentoring and tandem partners need to have access to training offers supporting the reflection of their very own knowledge and work experience. Another important factor is the employment contract of each cooperation partner: The fear of senior employees losing their job after having successfully transferred their knowledge has to be softened by a long-term contract. Young employees, on the other hand, also need a secure and interesting prospect in the company: short-term contracts and low salaries (compared with their older colleagues) are likely to lead to a decline in motivation for effective team work (Zimmermann 2005, pp. 29f.; Dworschak 2010, n.pag.; Klaffke and Schwarzenbart 2013, p. 47; Seitz and Wagner 2009, pp. 165ff.).

Bader et al. (2009) suggest that measures for knowledge preservation in enterprises may open up chances and opportunities for mutual exchange and learning, but are often unstructured and will not provide for an efficient transfer of relevant knowhow. Outside the framework of systematised learning and teaching processes, knowledge transfer happens only spontaneously. The challenge to transfer knowledge (that 
refers predominantly to situation-related routines) without a systematic elaboration and structured preparation often puts knowledge bearers under strain. The success of knowledge transfer then depends on the knowledge receivers, who have to identify transfer impulses and integrate them in their own field of action and experience. The authors emphasise that the main task in this context is to identify transfer-relevant experience - not every piece of knowledge offered by senior employees is important for their younger colleagues. Executive managers should get involved to analyse and identify relevant types of knowledge (technical knowledge, project know-how, network contacts etc.). In order to systematise knowledge transfer in companies, Bader, Riese \& Piorr propose an intergenerational knowledge management model in seven steps - the so-called Nova. PE transfer cycle that was developed for small and medium-sized companies (Bader et al. 2009, pp. 38ff.; see also Piorr et al. 2006; Seitz and Wagner 2009, p. 167).

\section{Short-Sighted Strategies and the Dominance of Monetary Key Figures}

The quotations and practical examples above show that German enterprises are becoming increasingly aware of the impact of demographical change and the necessity for intergenerational knowledge transfer. Nevertheless, the implementation of adequate measures happens too slowly and only sporadically. A holistic intergenerational personnel strategy is still the exception. The economic focus is narrowed to monetary key figures, even more so in uncertain economic times. Demography, age and generation have become topics that are discussed in companies, but only as second-rate categories (Seitz and Wagner 2009, p. 171). In the perspective of many firms, the threat of demographic change still seems to be lurking only in the distant future - compared to many other, seemingly more acute problems (Eck et al. 2013, pp. 36ff.; Berblinger et al. 2013, pp. 394ff.). However, in the face of demographic change - happening also in times of recession and financial crisis - companies should no longer be reluctant to anticipate its consequences (even if these might not yet have surfaced) and to react adequately by establishing a 'holistic' intergenerational personnel strategy (Eck et al. 2013, pp. 41f.; Seitz and Wagner 2009, p. 171).

\section{Conclusion}

The German case shows that workforce development has various facets. Besides formalised pathways, especially in the craft sector, companies rely on their own strategies. One crucial challenge seems to be demographic change as companies have to be aware that they need instruments to keep their workforce skilled but also to secure the qualifications and competences of the younger generation. Nobody can 
anticipate at the moment whether the German economy, with its comparatively strong industrial sector, will recruit more skilled personnel from higher education in the future. At the moment, the traditional pathways, above all the dual apprenticeship system, seem to be relevant and attractive and also remain the focus of national VET policy.

\section{References}

Arnold, R., \& Hülshoff, T. (1981). Rekrutierung und qualifikation des betrieblichen Bildungspersonals. Heidelberg: Esprint-Verlag.

AUDI AG. (2014). Diversity - Individualität und Persönlichkeit. URL: http://www.audi.de/de/ brand/de/unternehmen/karriere_bei_audi/arbeiten_bei_audi/diversity.html. 24 Feb 2014.

Bader, K., Riese, C., \& Piorr, R. (2009). Wissen und Erfahrungen älterer Beschäftigter vererben. Ein Modell zum intergenerativen Wissenstransfer in Unternehmen. Berufsbildung in Wissenschaft und Praxis, 2009(1), 38-41.

Baethge, M., Solga, H., \& Wieck, M. (2007). Berufsbildung im Umbruch. Signale eines überfälligen Aufbruchs. Berlin: Friedrich-Ebert-Stiftung.

Berblinger, S., Ďuranová, L., \& Knörzer, M. (2013). Demografiemanagement in deutschen Unternehmen. In M. Göke \& T. Heupel (Eds.), Wirtschaftliche Implikationen des demografischen Wandels. Herausforderungen und Lösungsansätze (pp. 383-397). Wiesbaden: Springer Gabler.

Boockmann, B., Fries, J., \& Göbel, C. (2013). Specific measures for older employees and late career employment (ZEW Discussion Paper No. 12-059). URL: http://ftp.zew.de/pub/ zew-docs/dp/dp12059.pdf. 25 Feb 2014.

Bossmann, U., Schweitzer, J., \& Schenck, K. (2013). Können und Dürfen: Zur Leistungsfähigkeit jüngerer und älterer Mitarbeiter. In J. Schweitzer \& U. Bossmann (Eds.), Systemisches Demografiemanagement. Wie kommt Neues zum Älterwerden in Unternehmen? (pp. 45-62). Wiesbaden: Springer VS.

Bundesinstitut für Berufsbildung. (2005). Referenz-Betriebs-System (RBS). Information No. 28. Betriebliche Weiterbildung älterer Beschäftigter. URL: http://www.bibb.de/de/12366.htm. 16 Feb 2014.

Bundesinstitut für Berufsbildung. (2009). Datenreport zum Berufsbildungsbericht 2009. Bonn: Bundesinstitut für Berufsbildung.

Bundesinstitut für Berufsbildung. (2012). Datenreport zum Berufsbildungsbericht 2012. Bonn: Bundesinstitut für Berufsbildung.

Bundesinstitut für Berufsbildung. (2013). Datenreport zum Berufsbildungsbericht 2013. Bonn: Bundesinstitut für Berufsbildung.

Bundesministerium für Bildung und Forschung. (2005). Die Reform der beruflichen Bildung Berufsbildungsgesetz 2005. Bonn: BMBF.

Bundesministerium für Bildung und Forschung. (2011). Deutscher Qualifikationsrahmen für Lebenslanges Lernen. Berlin: BMBF.

Cihlar, V., Mergenthaler, A., \& Micheel, F. (2014). Erwerbsarbeit \& Informelle Tätigkeiten der 55- bis 70-Jährigen in Deutschland. Wiesbaden: Bundesinstitut für Bevölkerungsforschung.

Daimler, A. G. (2013). 'Space cowboys - Daimler Senior Experts' starten mit Projekteinsätzen. URL:http://media.daimler.com/dcmedia/0-921-1281854-49-1594591-1-0-1-0-0-1-0-614232-0-10-0-0-0-0.html. 22 Feb 2014.

Daimler, A. G. (2014). Erfahren in die Zukunft - das Generationenmanagement bei Daimler. URL:http://blog.daimler.de/2014/01/07/erfahren-in-die-zukunft-das-generationenmanagementbei-daimler/. 22 Feb 2014. 
Deissinger, T. (1994). The evolution of the modern vocational training systems in England and Germany: A comparative view. Compare, 24, 17-36.

Deissinger, T. (1996). Germany's Vocational Training Act: Its function as an instrument of quality control within a tradition-based vocational training system. Oxford Review of Education, 22(3), 317-336.

Deissinger, T. (2000). The German 'philosophy' of linking academic and work-based learning in higher education - The case of the 'Vocational Academies'. Journal of Vocational Education and Training, 52(4), 609-630.

Deissinger, T. (2009). Curriculare Vorgaben für Lehr-Lernprozesse in der beruflichen Bildung. In B. Bonz (Ed.), Didaktik und Methodik der Berufsbildung (Berufsbildung konkret, Bd. 10, pp. 60-88). Hohengehren: Schneider.

Deissinger, T. (2010). Dual system. In P. Peterson, E. Baker, \& B. McGaw (Eds.), International encyclopedia of education (3rd ed., Vol. 8, pp. 448-454). Oxford: Elsevier.

Deissinger, T., Smith, E., \& Pickersgill, R. (2006). Models of full-time and part-time vocational training for school-leavers: A comparison between Germany and Australia. International Journal of Training Research, 4(1), 30-50.

Deissinger, T., Heine, R., \& Ott, M. (2012). The dominance of apprenticeships in the German VET system and its implications for Europeanisation - A comparative view in the context of the EQF and the European LLL strategy. In A. Fuller \& L. Unwin (Eds.), Contemporary apprenticeship: International perspectives on an evolving model of learning (pp. 160-179). London: Routledge.

Deissinger, T., Aff, J., Fuller, A., \& Jorgensen, C. H. (Eds.). (2013). Hybrid qualifications: Structures and problems in the context of European VET policy. Bern: Peter Lang.

Dworschak, B. (Fraunhofer-Institut für Arbeitswirtschaft und Organisation IAO). (2010). Quoted in Frankfurter Allgemeine Zeitung (FAZ.NET), Beruf \& Chance vom 26.08.2010. URL: http:// www.faz.net/aktuell/beruf-chance/arbeitswelt/demographie-alte-hasen-junge-huepfer11028122.html. 22 Feb 2014.

Eck, A., \& Bossmann, U. (2013). Demografischer Wandel: Eine kurze Einführung in eine populäre Prognose. In J. Schweitzer \& U. Bossmann (Eds.), Systemisches Demografiemanagement. Wie kommt Neues zum Älterwerden in Unternehmen? (pp. 15-24). Wiesbaden: Springer VS.

Eck, A., Zwack, M., \& Bossmann, U. (2013). Wen muss das interessieren? Die Relevanz des demografischen Wandels für Mitarbeiter, Führungskräfte und Organisationen. In J. Schweitzer \& U. Bossmann (Eds.), Systemisches Demografiemanagement. Wie kommt Neues zum Älterwerden in Unternehmen? (pp. 25-44). Wiesbaden: Springer VS.

Euler, D. (1998). Modernisierung des dualen Systems - Problembereiche, Reformvorschläge, Konsens- und Dissenslinien (Materialien zur Bildungsplanung und zur Forschungsförderung, 62). Bonn: Bund-Länder-Kommission für Bildungsplanung und Forschungsförderung.

Euler, D., \& Severing, E. (2006). Flexible Ausbildungswege in der Berufsbildung. Nürnberg: Typoskript.

Frassek, D. (2014). Eine Chance und Bereicherung. Im Gespräch mit Dietmar Frassek. Wissenschaftsjahr 2013 - Die demografische Chance. Eine Initiative des Bundesministeriums für Bildung und Forschung. URL: http://www.demografische-chance.de/die-themen/stimmenaus-der-gesellschaft/eine-chance-und-bereicherung.html. 24 Feb 2014.

Hake, B. J. (1999). Lifelong learning policies in the European Union: Developments and issues. Compare, 29(1), 53-70.

Harris, R., \& Deissinger, T. (2003). Learning cultures for apprenticeships: A comparison of Germany and Australia. In J. Searle, I. Yashin-Shaw, \& D. Roebuck (Eds.), Enriching learning cultures (Vol. 2, pp. 23-33). Brisbane: Australian Academic Press.

Hippach-Schneider, U., \& Weigel, T. (2012). VET qualifications versus bachelor degrees? Recruitment at the intermediate qualification level - Case studies from Germany, England and Switzerland. In M. Pilz (Ed.), The future of vocational education and training in a changing world (pp. 259-272). Wiesbaden: Springer VS. 
Joshi, A., \& Roh, H. (2009). The role of context in work team diversity research: A meta-analytic review. Academy of Management Journal, 52(3), 599-627.

Klaffke, M., \& Schwarzenbart, U. (2013). Demografie als Chance. Personalmagazin, 13(3), 44-47.

Knörr, M. (1996). Die Berufszulassung zum Handwerk seit dem Ende des Alten Reiches. Dissertation. Nürnberg.

Lesser, E., Hausmann, C., \& Feuerpeil, S. (2005). Die Herausforderungen des demografischen Wandels: Strategische Handlungsfelder für Unternehmen in Europa. Stuttgart/Wien/Zürich: IBM.

Luhmann, N. (1984). Soziale Systeme - Grundriss einer allgemeinen Theorie. Frankfurt a.M.: Suhrkamp.

Meyers, R. A. (2009). Mitarbeiter im neuen Millennium - Kommunikation zwischen den Generationen. In G. Richter (Ed.), Generationen gemeinsam im Betrieb. Individuelle Flexibilität durch anspruchsvolle Regulierungen (pp. 202-220). Bielefeld: Bertelsmann.

Oertel, J. (2007). Generationenmanagement in Unternehmen. Schriften aus dem Centrum für Management. Wiesbaden: Deutscher Universitäts-Verlag.

Piorr, R., Reckermann, A., \& Riese, C. (2006). Damit Know-how und Erfahrung nicht in Rente gehen! Konzepte für den systematischen Wissenstransfer zwischen Generationen. SPECIAL Personalführung, 7, 82-89.

Ries, B. C., Diestel, S., Wegge, J., \& Schmidt, K.-H. (2010). Die Rolle von Alterssalienz und Konflikten in Teams als Mediatoren in der Beziehung zwischen Altersheterogenität und Gruppeneffektivität. Zeitschrift für Arbeits- und Organisationspsychologie, 54(3), 117-130.

Robert Bosch GmbH. (2009). Seit zehn Jahren: Karriere nach der Karriere. Bosch Management Support verfügt über 26000 Jahre Erfahrung. Presse-Information. URL: http://www.boschpresse.de/presseforum/details.htm?txtID=4269\&tk_id=191. 22 Feb 2014.

Ryan, P. (2001). Apprenticeship in Britain - Tradition and innovation. In T. Deissinger (Ed.), Berufliche Bildung zwischen nationaler Tradition und globaler Entwicklung (pp. 133-157). Baden-Baden: Nomos Verlag.

Ryan, P. (2003). Evaluating vocationalism. European Journal of Education, 38(2), 147-162.

Schenck, K. (2013). Qualifizierung und Wissensmanagement: Wie Know-how im Unternehmen bleibt. In J. Schweitzer \& U. Bossmann (Eds.), Systemisches Demografiemanagement. Wie kommt Neues zum Älterwerden in Unternehmen? (pp. 125-146). Wiesbaden: Springer VS.

Schweitzer, E. (Deutscher Industrie- und Handelskammertag). (2014). Quoted in Spiegel Online, Azubi-Mangel: Wirtschaftsboss wettert gegen Akademisierung vom 03.02.2014. URL: http:// www.spiegel.de/wirtschaft/dihk-praesident-schweitzer-akademisierung-schadetwirtschaftsstandort-a-950708.html. 1 Mar 2014.

Schwichtenberg, U. (1991). Qualifizierung für die Ausbildertätigkeit. Eine kritische Betrachtung der Vorbereitungskurse für die Prüfung nach der Ausbildereignungsverordnung. In M. Frackmann (Ed.), Qualifizierungsbedarf und Weiterbildungsangebote für betriebliches Ausbildungspersonal (pp. 25-40). Alsbach: Leuchtturm.

Seitz, C., \& Wagner, M. H. (2009). Wissen intergenerativ erzeugen und transferieren - die Chancen intergenerativer Zusammenarbeit. In G. Richter (Ed.), Generationen gemeinsam im Betrieb. Individuelle Flexibilität durch anspruchsvolle Regulierungen (pp. 157-172). Bielefeld: Bertelsmann.

SICK AG. (2010). Altersgemischte Teams in der SICK AG. URL: http://www.inqa.de/SharedDocs/ PDFs/DE/Gute-Praxis/Sick-Altersgemischte-Teams-in-der-Sick-AG.pdf?_blob=publicationFile. 22 Feb 2014.

Statistische Ämter des Bundes und der Länder. (2011). Demografischer Wandel in Deutschland. Bevölkerungs- und Haushaltsentwicklung im Bund und in den Ländern. Wiesbaden: Statistisches Bundesamt.

Statistisches Bundesamt. (2009). Bevölkerung Deutschlands bis 2060. 12. Koordinierte Bevölkerungsvorausberechnung. Wiesbaden: Statistisches Bundesamt. 
Statistisches Bundesamt. (2013). Bildung und Kultur. Berufliche Bildung 2012. Fachserie 11 Reihe 3. Wiesbaden: Statistisches Bundesamt.

Steedman, H. (2010). The state of apprenticeship in 2010: International comparisons. London: London School of Economics.

Stratmann, K., \& Pätzold, G. (1984). Institutionalisierung der Berufsbildung. In M. Baethge \& K. Nevermann (Eds.), Enzyklopädie Erziehungswissenschaft, Vol. 5: Organisation, Recht und Ökonomie des Bildungswesens (pp. 114-134). Stuttgart: Klett-Cotta.

Stratmann, K., \& Schlüter, A. (Eds.). (1982). Quellen und Dokumente zur Berufsbildung, 1794-1869. Köln: Böhlau.

Tomenendal, M. (2013). Zur Effektivität altersgemischter Teams - die Fallstudie eines mittelständischen Dienstleistungsunternehmens. In M. Göke \& T. Heupel (Eds.), Wirtschaftliche Implikationen des demografischen Wandels. Herausforderungen und Lösungsansätze (pp. 433-443). Wiesbaden: Springer Gabler.

Walter, N., Fischer, H., Hausmann, P., Klös, H.-P., Lobinger, T., Raffelhüschen, B., Rump, J., Seeber, S., \& Vassiliadis, M. (2013). Die Zukunft der Arbeitswelt. Auf dem Weg ins Jahr 2030. Stuttgart: Robert Bosch Stiftung GmbH.

Weber, R. (1985). Berufsbildungsgesetz und Berufsbildungsförderungsgesetz. Bergisch-Gladbach: Heider.

Wegge, J., Roth, C., \& Schmidt, K.-H. (2008). Eine aktuelle Bilanz der Vor- und Nachteile altersgemischter Teamarbeit. Wirtschaftspsychologie, 10(3), 30-43.

Wegge, J., Jungmann, F., Liebermann, S., Schmidt, K.-H., \& Ries, B. C. (2011). Altersgemischte Teamarbeit kann erfolgreich sein. Empfehlungen für eine ausgewogene betriebliche Altersstruktur. Sozialrecht + Praxis, 21(7), 433-442.

Wilhelm, T. (1957). Die Pädagogik Kerschensteiners. Stuttgart: Metzler.

Winkler, H. A. (1976). From social protectionism to national socialism: The German smallbusiness movement in comparative perspective. Journal of Modern History, 48, 1-18.

Young, M. (2003). National qualifications frameworks as a global phenomenon: A comparative perspective. Journal of Education and Work, 16(3), 223-237.

Zabeck, J. (1975). Die Bedeutung des Selbstverwaltungsprinzips für die Effizienz der betrieblichen Ausbildung. Untersuchung im Auftrage des Ministers für Wirtschaft, Mittelstand und Verkehr des Landes Nordrhein-Westfalen. Mannheim.

Zabeck, J. (2013). Geschichte der Berufserziehung und ihrer Theorie, 2. Aufl. Paderborn: Eusl.

Zimmermann, H. (2005). Kompetenzentwicklung durch Erfahrungstransfer. Betriebliche Ansätze zum Erfahrungstransfer zwischen älteren und jüngeren Beschäftigten. Berufsbildung in Wissenschaft und Praxis, 5, 26-30.

Zwack, M., \& Schweitzer, J. (2013). Unterschiede, die keine Unterschiede machen dürfen: Entstehung und Umgang mit Leistungsunterschieden in Arbeitsteams. In J. Schweitzer \& U. Bossmann (Eds.), Systemisches Demografiemanagement. Wie kommt Neues zum Älterwerden in Unterne. Dordrecht: Springer. 